\title{
The 1997 phreatic eruption of Akita-Yakeyama volcano, northeast Japan: Insight into the hydrothermal processes
}

\author{
Kenji Nogami ${ }^{1}$, Jun-ichi Hirabayashi ${ }^{1}$, Takeshi Ohba ${ }^{1}$, and Yuzo Yoshiike ${ }^{2}$ \\ ${ }^{1}$ Kusatsu-Shirane Volcano Observatory, Tokyo Institute of Technology, 641-36 Kusatsu, Agatsuma, Gunma 377-1711, Japan \\ ${ }^{2}$ Department of Chemistry, Faculty of Science, Toho University, 2-2-1 Miyama, Funabashi, Chiba 274-0072, Japan
}

(Received September 8, 1998; Revised January 20, 2000; Accepted January 20, 2000)

\begin{abstract}
A small-scale steam explosion occurred on Karanuma crater on the summit of Akita-Yakeyama volcano on August 16, 1997 after a dormancy of 46 years. Chemical compositions of the fumarolic gases at the summit and hot spring waters around the volcano were monitored before the eruption.

Obvious changes in the composition and outlet temperatures of the fumarolic gases were not detected, neither before nor after the 1997 eruption. Hydrogen and oxygen isotopic ratios of the gas condensates and hot-spring waters at the Yunuma crater indicated that a hydrothermal reservoir, where the fumarolic gases separated from the hot-spring waters at $150^{\circ} \mathrm{C}$, existed in a shallow place beneath the crater.

Smectite, kaolinite and pyrophyllite were identified in the clay fraction of the volcanic ejecta. Although pyrophyllite should have been formed at about $1 \mathrm{~km}$ beneath the summit, it was not directly derived from the deep zone during the 1997 eruption but had been ejected by previous eruptions. The $\mathrm{Cl} / \mathrm{S}$ values of the water leachates of the ejecta were about 0.7 , which indicated that the volcanic gas which caused the eruption was rich in $\mathrm{HCl}$. However, the fumarolic gases and the water samples collected from the summit area contained little chloride. The source of the water-soluble chloride might be high-temperature magmatic gases that have been estimated as the source of $\mathrm{Cl}-\mathrm{SO}_{4}$ type thermal water. Such magmatic gases might have caused the 1997 eruption.
\end{abstract}

\section{Introduction}

Volatile materials are the most mobile components in magmas. It has been generally acknowledged that the chemical composition and outlet temperature of fumarolic gases change because of an increase in volatile components from magma as an eruption becomes imminent (e.g. Hirabayashi et al., 1999). The chemical composition and flux of volcanic gases can often provide information on subsurface conditions. Geochemical monitoring of volatile components from magma contributes towards forecasting volcanic eruptions.

Besides direct volcanic gas observation, some indirect methods have been devised for monitoring the chemical composition of gas discharged from active volcanoes. Boxes containing an alkaline $(\mathrm{KOH})$ solution were installed to absorb ambient gases from some volcanoes in order to obtain an average composition of the gaseous constituents discharged from an active crater over a certain period (Noguchi and Kamiya, 1963; Hirabayashi et al., 1982).

An analysis of water leachates of pristine ashes is used to estimate the composition of the gas phase during eruption (Taylor and Stoiber, 1973; Ossaka and Ozawa, 1975; Rose, 1977; Ossaka et al., 1998). Varekamp et al. (1984) stated that the concentration of volcanic gas components adhering to the ashes was controlled by the composition of the vapor phase, time spent in the volcanic plume, surface area of the ash particles, and many other factors. Ossaka and Ozawa (1975) observed that $\mathrm{Cl}^{-} / \mathrm{SO}_{4}^{2-}$ molar values in the water leachates of the volcanic ashes were almost equal to the $\mathrm{HCl} / \mathrm{SO}_{2}$ molar values in the volcanic gases diffusing in the atmosphere. Investigating the water leachates of ashes is a safe and effective method for monitoring of volcanic activity without having to use particular equipment.

Clay minerals are often contained in volcanic ejecta, in particular as a result of steam explosions. Since the stability of clay minerals depends on such conditions as temperature, pressure and $\mathrm{pH}$, the physical and chemical conditions from which the ejecta were derived can be estimated by studying the clay minerals in the ejecta. Clay minerals were investigated in the volcanic ashes from Yakedake in 1962 (Ossaka and Ozawa, 1966), Kusatsu-Shirane in 1982-1983 (Kurosaki et al., 1990), Usu in 1977 (Matsuo et al., 1977), Kiso-Ontake in 1979 (Ossaka et al., 1983), Hokkaido-Komagatake in 1996 (Ui et al., 1997) and Kirishima in 1991-1992 (Hirabayashi et al., 1996b).

A small-scale steam explosion occurred at AkitaYakeyama volcano on August 16, 1997 after dormancy for 46 years opening new vents. Fumarolic gases, hot-spring water and crater lake water were collected at the summit area for chemical and isotope analysis. Volcanic ejecta were also sampled for clay-mineral analysis. The relationship between this eruption and the hydrothermal system in this volcano is discussed based on these geochemical data. 


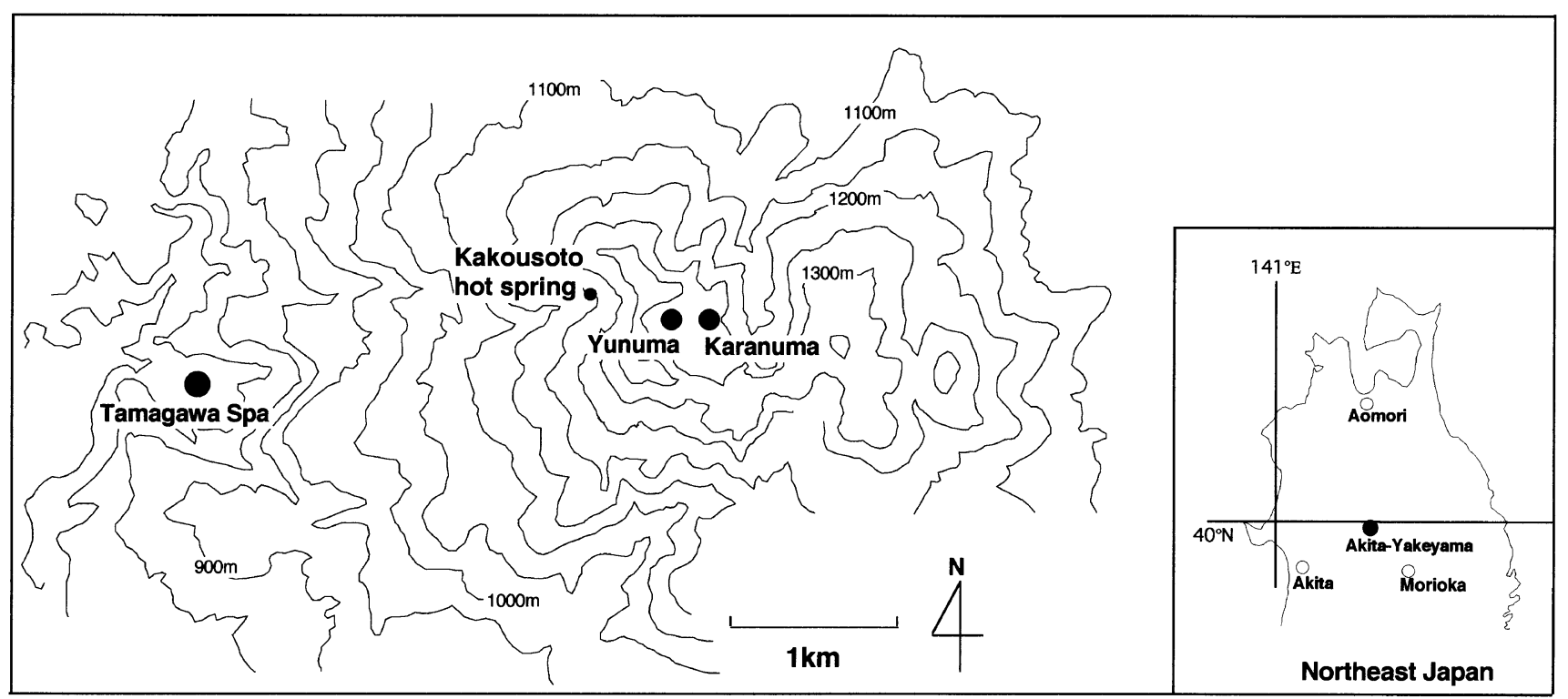

Fig. 1. Location of the Yunuma and Karanuma craters at the summit of the Akita-Yakeyama volcano, northern Tohoku, Japan. The Obuki hot spring is located at the Tamagawa Hot Spa on the western flank of the volcano.

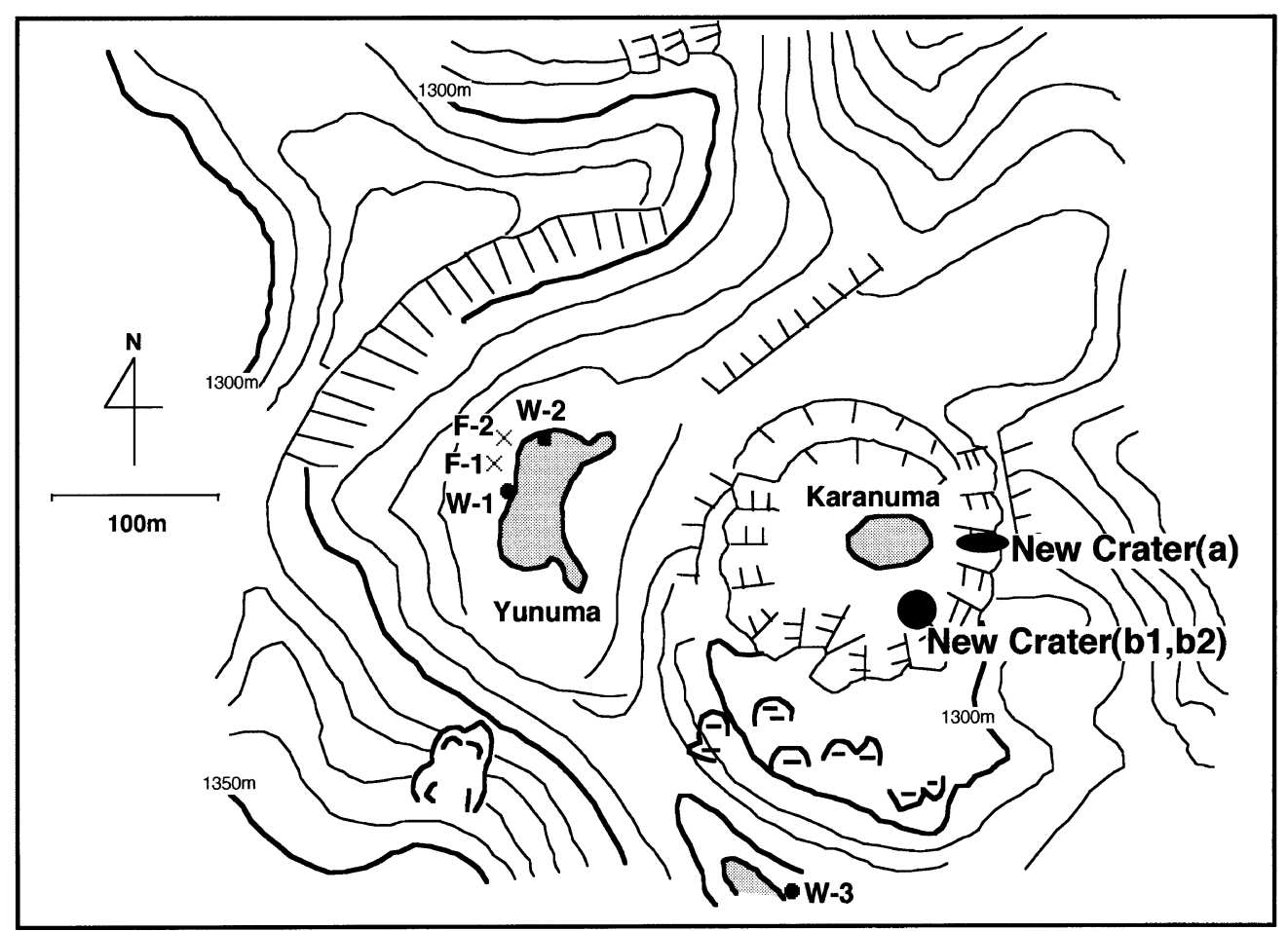

Fig. 2. Locality of volcanic gas and water samples from the Yunuma and Karanuma craters at the summit area of Akita-Yakeyama. The names of the new craters at Karanuma (a, b1 and b2) are from Hayashi et al. (1997). Volcanic gas samples: $\times$ water samples:

\section{Sampling and Analysis}

\subsection{Geological situation and the 1997 eruption}

The Akita-Yaeyama volcano is located in the northern Tohoku area of Japan $\left(39^{\circ} 58^{\prime} \mathrm{N} 140^{\circ} 46^{\prime} \mathrm{E}, 1366\right.$ m, Fig. 1) and has a central cone of dacite. It has two major craters, Karanuma and Yunuma, located at the summit (Fig. 1). Karanuma is a circular crater with a diameter of about $100 \mathrm{~m}$. No active fumaroles and hot-springs are situated in and around that crater. Yunuma is an oval crater lake whose size is about $100 \mathrm{~m} \times 50 \mathrm{~m}$ (Fig. 2). A fumarolic area extends to the north of the lake and bubble gas issues everywhere in the lake.

A steam plume rising from the Karanuma crater was observed at about 11:00 on August 16, 1997 and a volcanic tremor continued for about one hour at the same time. When the staff of the Akita Meteorological Observatory researched 
the area around the crater on August 17, discharge of volcanic gases from the new vents had completely stopped. When we surveyed the fumarolic area at the summit on August 20, volcanic gases had not been discharged from the new vents and no earthquake tremors were felt around the summit crater.

All the historic eruptions of Akita-Yakeyama were steam explosions and all occurred at the Karanuma crater (JMA, 1996). Tsuya (1954) investigated the location and form of the vents opened by the eruptions of 1949 and 1951 at Karanuma and the distribution of the volcanic ejecta from those vents in detail. Three vents (a, b1, and b2) were opened on August 16,1997 at the same place as those of the old vents of the 1949 and 1951 eruptions, judging from the pictures taken in 1953. Volcanic bombs and muddy ashes were ejected from vent a and mud flows ran out from vents b1 and b2 (Hayashi et al., 1997).

Muddy volcanic ashes from vent a were sprayed onto the southern wall of the Karanuma crater and extended about $300 \mathrm{~m}$ south of the new vent. Samples for clay-mineral analysis were collected from leaves of bamboo grass in order to escape contamination by soil. Volcanic ash that has not been rained on is necessary for the analysis of water-soluble components but the ashes collected on August 20 had unfortunately been rained on. Fresh ashes from the 1997 vents collected on August 17, were provided by Dr. Tsukasa Ohba and Mr. Kiyohisa Kuroda.

\subsection{Clay minerals in the volcanic ejecta}

Constituent minerals of the volcanic ejecta, especially clay minerals, were investigated. Clay fractions were extracted from the volcanic ash samples by following the methods for X-Ray Diffraction (XRD) analysis. The ash samples were stirred in ion exchanged water and a clay fraction of less than $2 \mu \mathrm{m}$ was separated by the sedimentation method. The clay particles were spread on slide glasses for orientation and airdried at room temperature. XRD patterns of the oriented samples of the clay fraction were obtained by using a diffractometer (X-part APD, PHILIPS Co. Ltd.) with $\mathrm{Cu}-\mathrm{K} \alpha$ radiation following three patterns at room temperature; first without any treatment, second with ethylene glycol treatment and third after heating at $600^{\circ} \mathrm{C}$ for 1 hour. XRD data were collected in the $2 \theta$ range from $2^{\circ}$ to $25^{\circ}$ by step scanning with a step interval of $0.02^{\circ}$.

\subsection{Water-soluble components on the ejecta}

About $5 \mathrm{~g}$ of each ash sample was correctly weighed and warmed on a hot plate for 24 hours with about $70 \mathrm{ml}$ of pure water. The solution was transferred to a $100 \mathrm{ml}$ measuring flask through Toyo 5A filter paper and diluted to the mark with pure water. Concentrations of chloride and sulfate ions in the solution were determined by an ionchromatograph (QIC ANALYZER, Dionex Co.). A pH meter (EA920, Orion Research Co.) with a glass electrode (Ross 81-02, Orion Research Co.) was used for $\mathrm{pH}$ measurement of the water leachates.

\subsection{Fumarolic gases}

Fumarolic gas samples were collected from the F-1 and F-2 fumaroles on the northern side of the Yunuma crater lake (Fig. 2). Outlet temperatures of fumaroles F-1 and F-2 were $104.7^{\circ} \mathrm{C}$ and $104.1^{\circ} \mathrm{C}$, respectively. Sampling and analysis of the fumarolic gases were carried out by the method devised by Ozawa (1968). Chemical monitoring of the F-1 fuma- role was continued from 1984 until 1996. Only the relative contents of $\mathrm{H}_{2} \mathrm{~S}, \mathrm{CO}_{2}$ and R-gas were determined because of the method fumarolic gas sampling and analysis from the simplified procedure of Ozawa (1968). R-gas is a generic term of gases, such as $\mathrm{He}, \mathrm{H}_{2}, \mathrm{O}_{2}, \mathrm{~N}_{2}, \mathrm{CH}_{4}$ and $\mathrm{Ar}$, which are not absorbed in alkaline solution.

Fumarolic gas condensates were also collected to determine the $\mathrm{D} / \mathrm{H}$ and ${ }^{18} \mathrm{O} /{ }^{16} \mathrm{O}$ ratios of $\mathrm{H}_{2} \mathrm{O}$. The condensate was equilibrated with $\mathrm{H}_{2}$ gas from a gas cylinder over $\mathrm{Pt}$ catalysis at $25^{\circ} \mathrm{C}(\mathrm{Ohba}$ and Hirabayashi, 1996). The $\mathrm{D} / \mathrm{H}$ ratio of the equilibrated $\mathrm{H}_{2}$ gas was measured by a mass spectrometer (MAT252, ThermoQuest Co. Ltd.). The same sample was used for measuring the ${ }^{18} \mathrm{O} /{ }^{16} \mathrm{O}$ ratio using the conventional $\mathrm{CO}_{2}-\mathrm{H}_{2} \mathrm{O}$ equilibration method (Epstein and Mayeda, 1953).

\subsection{Lake water and hot-spring water}

Hot-spring water discharging bubble gases was collected at W-1 on the northern shore of Yunuma (Fig. 2). The temperature of this hot-spring water was $92.0^{\circ} \mathrm{C}$, which is a few degrees lower than the boiling point at the summit. We chose $\mathrm{W}-2$ for the sampling point of the lake water in order to reduce contamination of the hot-spring water. Pond water was sampled at W-3 as a sample of meteoric water at the summit area (Fig. 2). No active fumaroles and hot-springs are located in the vicinity of the pond. Determination of the concentrations of chloride and sulfate ions in the water samples and measurement of the $\mathrm{pH}$ were carried out in the same manner as shown in Section 2-3.

Hot spring water sampled during 1992-1998 at Obuki, Kagamizawa and Sesshokubo at Tamagawa Spa and Kakousoto near the summit area were also analyzed. The concentration of chloride and sulfate ions in the samples were determined by titration (Volhard method) and gravimetry as $\mathrm{BaSO}_{4}$, respectively.

\section{Results and Discussion}

\subsection{Chemical composition of fumarolic gases and hot} spring water

Major constituents, exclusive of water, of the fumarolic gases sampled at F-1 and F-2 were $\mathrm{H}_{2} \mathrm{~S}$ and $\mathrm{CO}_{2}$ (Table 1). The ratio of $\mathrm{SO}_{2} / \mathrm{H}_{2} \mathrm{~S}$ was less than 0.01 and the ratio of $\mathrm{HCl} / \mathrm{SO}_{2}$ was in the order of 0.1 . These are characteristic of low temperature volcanic gases (e.g. Iwasaki et al., 1966). The chemical composition of the fumarolic gases between 1984 and 1996 did not change much during the last few years (Fig. 3). The outlet temperature of the fumarole F-1 was almost constant between 102 and $107^{\circ} \mathrm{C}$ from 1984 to 1997. Obvious changes in the gas composition and the outlet temperature were neither detected before or after the 1997 eruption.

The Obuki hot spring at Tamagawa Spa is the only acid Cl$\mathrm{SO}_{4}$ type in the geothermal area around the Akita-Yakeyama volcano and the concentration of $\mathrm{Cl}$ is higher than that of $\mathrm{SO}_{4}$. The discharge of heat and materials from the Obuki hot spring overwhelms those from the other hot springs and fumaroles at this volcano. The chloride concentration in the Kagamizawa and Sesshokubo hot spring waters at Tamagawa Spa and Kakousoto near the summit area were very low, being sulfate acidic (Table 2). The crater lake water and the hot spring water at the Yunuma crater were also sulfate acidic 
Table 1. Chemical composition of volcanic gases at the summit of Akita-Yakeyama.

\begin{tabular}{ccccccccccccccccc}
\hline & \multicolumn{1}{c}{} & \multicolumn{4}{c}{$\begin{array}{c}\text { composition of gases exclusive } \\
\text { of water (vol. \%) }\end{array}$} & \multicolumn{4}{c}{ composition of R-gas (vol. \%) } \\
\hline Locality & $\mathrm{T}\left({ }^{\circ} \mathrm{C}\right)$ & $\mathrm{H}_{2} \mathrm{O}($ vol. \%) & $\mathrm{HCl}$ & $\mathrm{SO}_{2}$ & $\mathrm{H}_{2} \mathrm{~S}$ & $\mathrm{CO}_{2}$ & $\mathrm{R}$ & $\mathrm{He}$ & $\mathrm{H}_{2}$ & $\mathrm{O}_{2}$ & $\mathrm{~N}_{2}$ & $\mathrm{CH}_{4}$ & $\mathrm{Ar}$ \\
F-1 & 104.7 & 98.6 & 0.02 & 0.25 & 37.7 & 61.3 & 0.74 & 0.057 & 0.626 & 1.40 & 97.5 & 0.034 & 0.428 \\
F-2 & 104.1 & 98.6 & 0.06 & 0.35 & 38.9 & 59.9 & 0.74 & 0.057 & 0.102 & 1.49 & 97.9 & 0.019 & 0.389 \\
\hline
\end{tabular}

Sampling date: August 20, 1997.

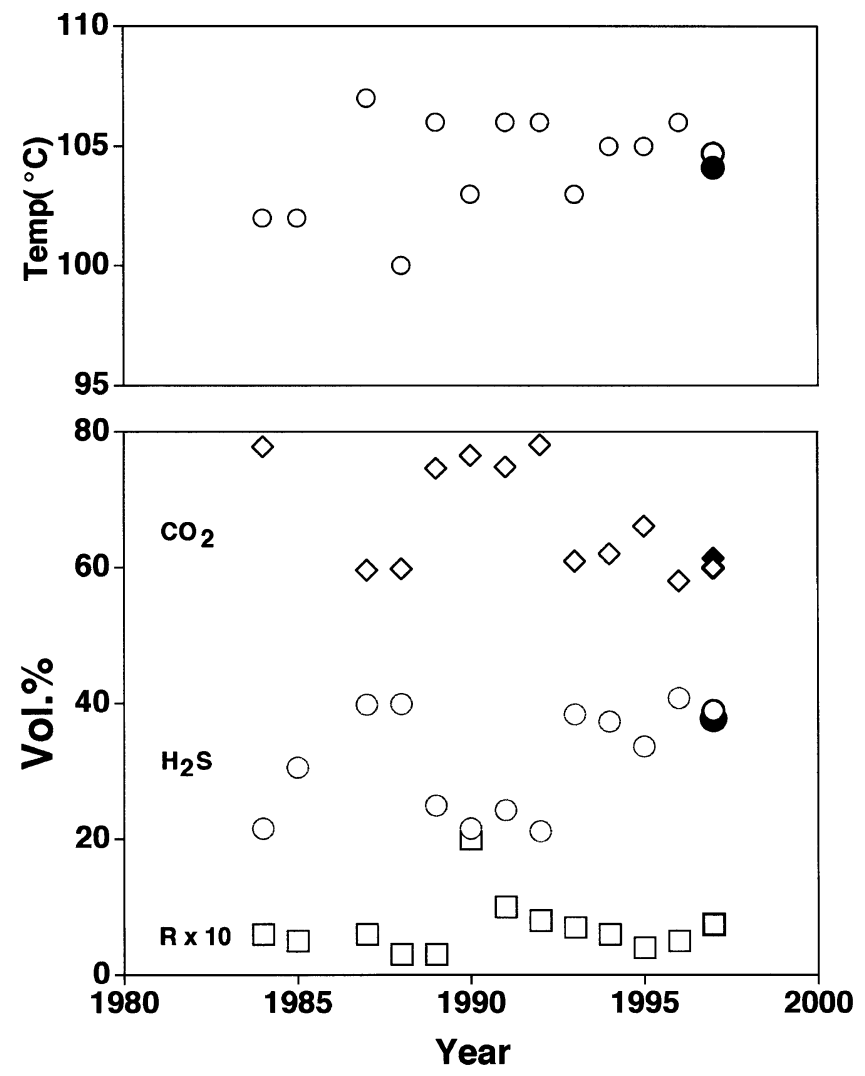

Fig. 3. Variation of outlet temperature and chemical compositions, exclusive of water of fumarolic gases, at F-1 ( 1997) and F-2 (1997). Open symbols: F-1 Closed symbols: F-2.

(Table 3). Acid springs located at a higher altitude than the Obuki hot spring contain very little chloride. Composition of these hot spring waters were not changed significantly by the eruption.

Iwasaki et al. (1966) showed the similarity of anion constituents between magmatic gas condensates from several volcanoes and the Obuki hot spring water and inferred that the Obuki hot spring was derived from high-temperature magmatic gas. Based on the characteristics in chemical composition and spatial distribution of the low-Cl springs, Iwasaki et al. (1966) inferred that the low $\mathrm{Cl}$ acid spring is derived from the vapor phase of a Cl-SO $\mathrm{S}_{4}$ type hydrothermal reservoir whose liquid phase forms the Obuki hot spring. Further, from the values of $\delta \mathrm{D}$ and $\delta^{18} \mathrm{O}$ of the spring water, Matsubaya et al. (1983) stated that a mixture of high temperature magmatic gas condensate and meteoric water constitutes the Obuki hot-spring water. High-temperature volcanic gas is mixed with underground water to form hydrothermal fluids and the fluid separates the vapor and liquid phases. The liquid phase concentrates fluoride and chloride ions, as well as sulfate ion formed by the self-redox reaction of $\mathrm{H}_{2} \mathrm{SO}_{3}$, and discharges as water from the Obuki hot spring. The vapor, relatively rich in $\mathrm{H}_{2} \mathrm{~S}$ and $\mathrm{CO}_{2}$ and separated from $\mathrm{Cl}-\mathrm{SO}_{4}$ type hydrothermal water, is mixed with meteoric water to form low-Cl acid hot spring water at high altitudes (Iwasaki et al., 1966; Matsubaya, 1991).

The hydrogen and oxygen isotope ratio of the gas condensates and the water samples collected at the summit area of this volcano are plotted in Fig. 4. The isotopic ratios of the gas condensates collected at F-1 and F-2 agree with those of the vapor equilibrated with the Yunuma hot spring water at $150^{\circ} \mathrm{C}$. This result suggests that a hydrothermal reservoir, where the fumarolic gases are separated from the hot spring water at $150^{\circ} \mathrm{C}$, exists beneath the Yunuma crater lake. Va- 
Table 2. Chemical composition of hot spring water around Akita-Yakeyama (in mg/l).

\begin{tabular}{|c|c|c|c|c|c|c|c|c|}
\hline Date & $\mathrm{Na}$ & $\mathrm{Ca}$ & $\mathrm{Mg}$ & $\mathrm{Fe}$ & $\mathrm{Al}$ & $\mathrm{SiO}_{2}$ & $\mathrm{Cl}$ & $\mathrm{SO}_{4}$ \\
\hline Aug. 31, '92 & 31 & 97 & 35 & 65 & 105 & 290 & 2400 & 900 \\
\hline Sep. 3, '93 & 32 & 108 & 39 & 73 & 119 & 304 & 2490 & 1050 \\
\hline Sep. 3, '94 & 35 & 107 & 37 & 74 & 123 & 307 & 2590 & 1080 \\
\hline Sep. 3, '95 & 35 & 100 & 35 & 63 & 105 & 302 & 2410 & 1020 \\
\hline Sep. 6, '96 & 54 & 97 & 41 & 64 & 99 & 307 & 2420 & 1010 \\
\hline Aug. 28, '97 & 39 & 106 & 30 & 71 & 83 & 288 & 2450 & 1060 \\
\hline \multicolumn{9}{|l|}{ Kakousoto } \\
\hline Date & $\mathrm{T}\left({ }^{\circ} \mathrm{C}\right)$ & $\mathrm{Na}$ & $\mathrm{K}$ & $\mathrm{Ca}$ & $\mathrm{Mg}$ & $\mathrm{Fe}$ & $\mathrm{Cl}$ & $\mathrm{SO}_{4}$ \\
\hline Sep. 6,'93 & 65 & 6.1 & 6.3 & 8.1 & 4.8 & 3.4 & 24.5 & 2300 \\
\hline Sep. 4, '94 & 60.5 & 7.4 & 6.6 & 9.1 & 6.1 & 2.0 & 33.5 & 2050 \\
\hline Sep. 4, '95 & 59 & 4.8 & 5.2 & 7.0 & 3.5 & 5.8 & 23.6 & 2150 \\
\hline Sep. 8, '96 & 62 & 5.7 & 6.2 & 8.0 & 4.9 & 2.4 & 35.8 & 2150 \\
\hline Aug. 30, '97 & 65 & 5.9 & 5.7 & 8.0 & 4.2 & 4.4 & 25.7 & 2200 \\
\hline \multicolumn{9}{|l|}{ Kagamizawa } \\
\hline Date & $\mathrm{T}\left({ }^{\circ} \mathrm{C}\right)$ & $\mathrm{Na}$ & $\mathrm{K}$ & $\mathrm{Ca}$ & $\mathrm{Mg}$ & $\mathrm{Fe}$ & $\mathrm{Cl}$ & $\mathrm{SO}_{4}$ \\
\hline Sep. 2,'95 & 98 & 3.7 & 3.2 & 5.0 & 2.2 & 34.0 & 1.4 & 2970 \\
\hline Sep. 6,'96 & 98 & 4.4 & 3.1 & 6.4 & 3.6 & 15.1 & 5.7 & 2060 \\
\hline Aug. 28, '97 & 98 & 4.1 & 3.1 & 4.9 & 2.6 & 21.1 & 8.5 & 2200 \\
\hline \multicolumn{9}{|l|}{ Sesshokubo } \\
\hline Date & $\mathrm{T}\left({ }^{\circ} \mathrm{C}\right)$ & $\mathrm{Na}$ & $\mathrm{K}$ & $\mathrm{Ca}$ & $\mathrm{Mg}$ & $\mathrm{Fe}$ & $\mathrm{Cl}$ & $\mathrm{SO}_{4}$ \\
\hline Sep. 2,'95 & 95 & 4.6 & 1.6 & 6.3 & 3.0 & 9.0 & 1.9 & 580 \\
\hline Sep. 6,' 96 & 95.4 & 4.7 & 1.7 & 6.3 & 2.7 & 15.5 & 2.1 & 470 \\
\hline Aug. 28, '97 & 95 & 5.5 & 2.1 & 7.3 & 3.1 & 13.0 & 2.6 & 410 \\
\hline
\end{tabular}

Table 3. Chemical and isotopic compositions of water samples.

\begin{tabular}{cccccccc}
\hline Sample & Date & Temp. $\left({ }^{\circ} \mathrm{C}\right)$ & $\mathrm{pH}$ & $\mathrm{Cl}^{(1)}$ & $\mathrm{SO}_{4}{ }^{(1)}$ & $\delta \mathrm{D}_{\text {SMOW }}{ }^{(2)}$ & $\delta \mathrm{O}_{\text {SMOW }}{ }^{(2)}$ \\
\hline HSW-YNM & Aug. 20, '97 & 92.0 & 1.84 & 4.1 & 1220 & -37 & -3.0 \\
LW-YNM & Aug. 20, '97 & 34.2 & 2.05 & 2.6 & 784 & -45 & -5.3 \\
PW & Aug. 20, '97 & - & 4.63 & 0.92 & 2.84 & -59 & -8.9 \\
F-1-C & Aug. 20,'97 & 104.7 & - & - & - & -48 & -6.0 \\
F-2-C & Aug. 20,'97 & 104.1 & - & - & - & -48 & -6.3 \\
\hline
\end{tabular}

${ }^{(1)}$ Unit is $\mathrm{mg} / \mathrm{l}$. ${ }^{(2)}$ Unit is \%o.

HSW-YNM: hot spring water at Yunuma, LW-YNM: Yunuma lake water, PW: pond water at the summit, F-1-C: condensate of volcanic gas at F-1 fumarole, F-2-C: condensate of volcanic gas at F-2 fumarole.

por rich in $\mathrm{H}_{2} \mathrm{~S}$ and $\mathrm{CO}_{2}$ and separated from the $\mathrm{Cl}-\mathrm{SO}_{4}$ type hydrothermal water, is likely to be the heat source of the hydrothermal reservoir. The vapor pressure of water at $150^{\circ} \mathrm{C}$ is 4.8 bar and the atmospheric pressure at the altitude of the sampling site is 0.86 bar. Pressure difference between the reservoir and the surface is 3.9 bar and the depth of the reservoir beneath the Yunuma crater lake is estimated to be about $39 \mathrm{~m}$ under hydrostatic conditions.

The $\delta \mathrm{D}$ and $\delta^{18} \mathrm{O}$ values of the lake water and the hot spring water were high compared to those for the pond water and 


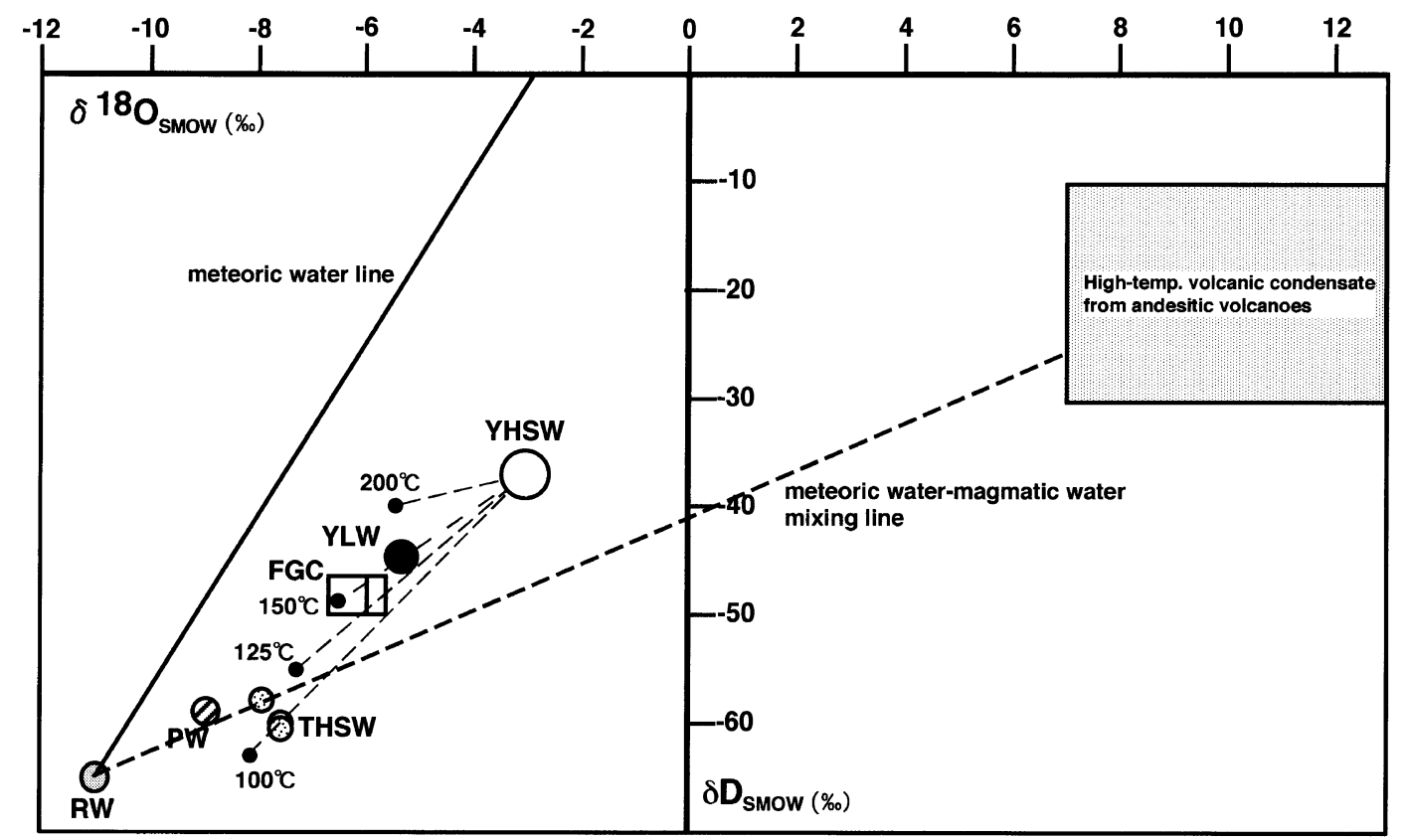

Fig. 4. Isotopic composition of the water and condensates samples at the summit area. $\delta \mathrm{D}$ and $\delta^{18} \mathrm{O}$ values for rain water and hot spring water at Tamagawa Spa are taken from Matsubaya et al. (1983). Closed circles with temperature indicate that isotopic composition of a vapor which equilibrates with the Yunuma hot-spring water at the indicated temperature. YHSW: Yunuma hot-spring water, YLW: Yunuma lake water, PW: pond water, FGC: fumarolic gas condensate, THSW: Tamagawa hot-spring water, RW: rain water.

rain water. Giggenbach (1992) showed that typical $\delta \mathrm{D}$ and $\delta^{18} \mathrm{O}$ values of high temperature fumarolic gas condensates discharged from andesitic volcanoes are $-20 \% \circ \pm 10$ and $+10 \pm 3 \%$, respectively. A mixture of high temperature volcanic gas and rain water can be the source of high $\delta \mathrm{D}$ and $\delta^{18} \mathrm{O}$ values for lake water and hot spring water. However, the $\delta \mathrm{D}$ and $\delta^{18} \mathrm{O}$ values of the water samples are not plotted on the mixing line between the rain water and high volcanic gas condensates. This result indicates that the lake water and the hot spring water, having high $\delta \mathrm{D}$ and $\delta^{18} \mathrm{O}$, values is not a simple mixture of high temperature volcanic gas and meteoric water.

\subsection{Clay minerals in the volcanic ejecta}

Pyrophyllite, kaolinite and smectite were identified in the clay fraction of the ejecta (Fig. 5). Presence of kaolinite was confirmed by the disappearance of the peak at $7 \AA$ during heat treatment at $600^{\circ} \mathrm{C}$. Migration of a reflection peak from $15 \AA$ to $17 \AA$ by the ethylene glycol treatment indicates the presence of smectite.

Kaolinite is principally formed by alteration of feldspar and other silicate minerals under weakly acidic hydrothermal conditions or by weathering of rock-forming silicate minerals and is stable in the Earth's surface environment. Smectite is formed by alteration of igneous rocks under alkaline conditions and is stable in underground environments which are not in contact with air (Ossaka, 1982). Because kaolinite and smectite are the major constituents in the clay fraction, the majority of the ejecta are derived from near the surface. In contrast, pyrophyllite formation requires relatively high pressure and high temperature conditions (e.g. Henmi and Matsuda, 1975). In the northern HachimantaiYakeyama area, 60 wells have been drilled for geothermal exploitation and extensive data have been accumulated con-

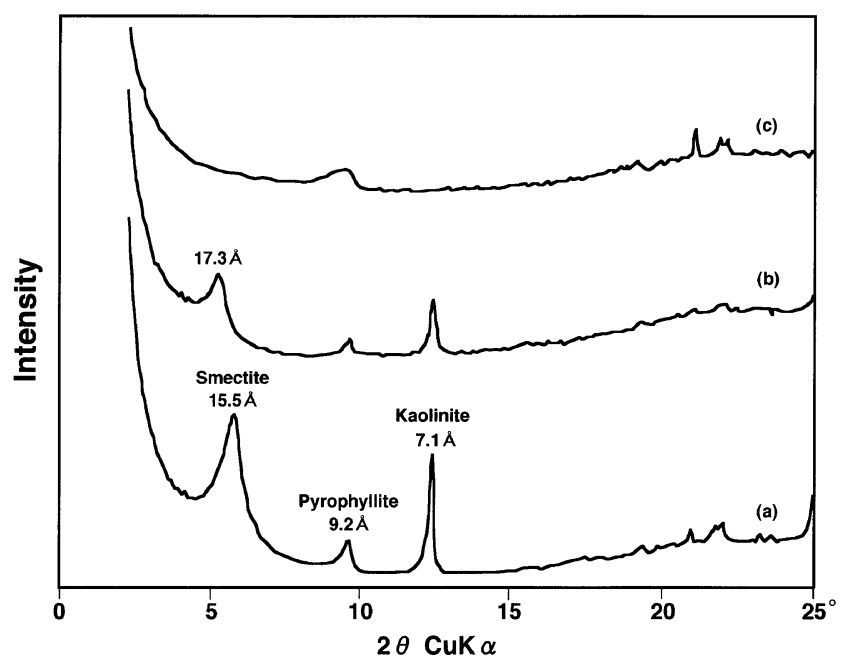

Fig. 5. XRD pattern of oriented clay fraction of volcanic ashes collected at the summit area: (a) without any treatment, (b) with ethylene glycol treatment, and (c) after heat treatment at $600^{\circ} \mathrm{C}$ for 1 hour.

cerning subsurface geology, temperature and other conditions. Banba and Kubota (1997) analyzed the conditions for secondary mineral formation and estimated the thermal history in this geothermal area and showed that the temperature of zones abundant in pyrophyllite is higher than $260 \pm 20^{\circ} \mathrm{C}$. The thermal contour at $260^{\circ} \mathrm{C}$ beneath the Yakeyama volcano is estimated to exist at an elevation of $0 \mathrm{~m}$ above sea level (Banba and Kubota, 1997). These results suggest that pyrophyllite in the ejecta were formed in deep zones about $1 \mathrm{~km}$ beneath the summit.

Hayashi et al. (1997) revealed that the orifice size of vent 
a was $15 \mathrm{~m} \times 8 \mathrm{~m}$ and $30 \mathrm{~m}$ in depth. The volume of the volcanic ash and mud flows are estimated to be $700 \mathrm{~m}^{3}$ and $2000 \mathrm{~m}^{3}$, respectively (Hayashi, per. com.). Suppose that vent a is a symmetric cone, the volume of the cone is calculated to be about $900 \mathrm{~m}^{3}$, which is comparable with the estimated volume of the volcanic ash. This result indicates that all the materials can be derived only from earthy materials near the surface. Judging from the location of the vents and the estimated volume of the ejecta, it is likely that the pyrophyllite in the ejecta was not transported directly from the deep zones by the 1997 eruption but had been discharged from the deep zones by past eruptions and deposited near the vents.

\subsection{Water-soluble components on the ejecta}

Concentrations of water-soluble $\mathrm{Cl}$ and $\mathrm{SO}_{4}$, and the $\mathrm{pH}$ values of the ash leachates are shown in Table 4. The ashes from vent a were rich in water-soluble components, especially chloride, compared with those from other volcanoes in Japan (Fig. 6). The ashes ejected by the steam explosion of Kusatsu-Shirane in 1976, that was attributed to relatively low-temperature volcanic gas (Hirabayashi et al., 1984), have low $\mathrm{Cl} / \mathrm{S}$ values for the water-soluble components of the ashes ranging 0.00 to 0.20 . To the contrary, the volcanic

Table 4. Contents of water-soluble anions on the volcanic ashes discharged on the eruption of Akita-Yakeyama in 1997.

\begin{tabular}{cccccc}
\hline No. & Date & $\mathrm{pH}$ & $\mathrm{Cl}^{(1)}$ & $\mathrm{SO}_{4}{ }^{(1)}$ & $\mathrm{Cl} / \mathrm{S}^{(2)}$ \\
\hline 1 & Aug. 17, '97 & 3.47 & 794 & 2880 & 0.74 \\
2 & Aug. 17, '97 & 3.54 & 1000 & 3960 & 0.68 \\
\hline
\end{tabular}

${ }^{(1)}$ Unit is $\mathrm{mg} / \mathrm{kg}$. ${ }^{(2)}$ Unit is molar ratio.

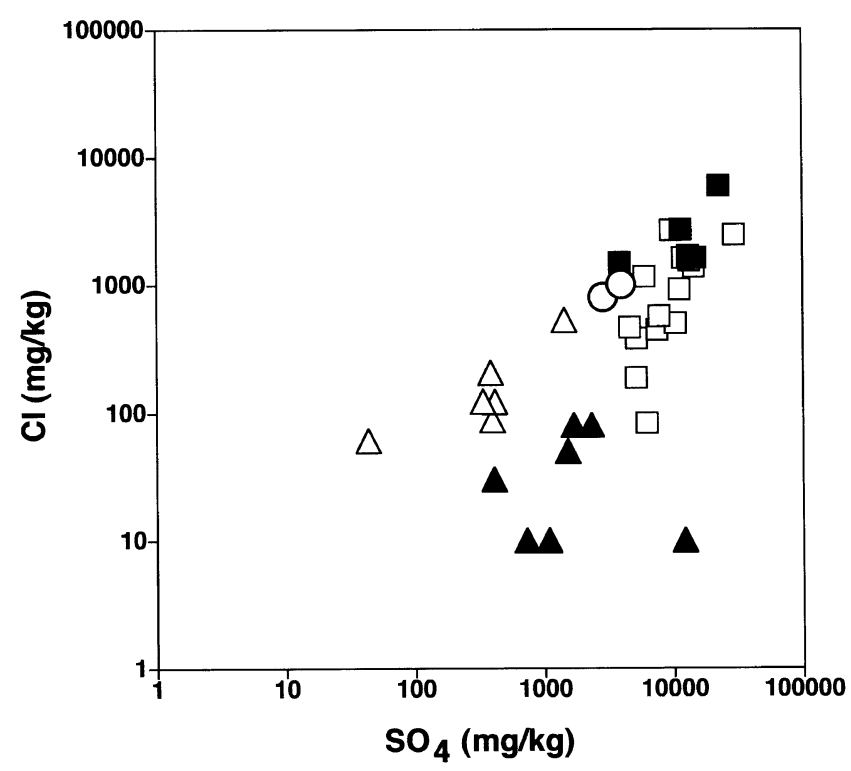

Fig. 6. Concentration of water-soluble chloride and sulfate adhering to the volcanic ashes from some volcanoes in Japan. $\bigcirc$ : this study, $\triangle$ : Usu (Matsuo et al., 1977), $\square$ : Tokachi (Ossaka et al., 1998), $\boldsymbol{\Delta}$ : Kusatsu-Shirane in 1976 (Hirabayashi, 1984), $\mathbf{\square}$ : Kiso-Ontake (Ossaka et al., 1983). ashes discharged by the eruptions of Usu in 1977 (Matsuo et al., 1977), Kiso-Ontake in 1979 (Ossaka et al., 1983), Sakurajima from 1973 to 1977 (Ossaka et al., 1977) and Kuju in 1995 (Hirabayashi et al., 1996a) that were caused by high-temperature volcanic gases, have high $\mathrm{Cl} / \mathrm{S}$ values ranging from 0.14 to 4.38 .

$\mathrm{The} \mathrm{Cl} / \mathrm{S}$ values of water leachates of the ashes from AkitaYakeyama are relatively high and comparable with those from an eruption caused by high temperature volcanic gases. Although $\mathrm{HCl}$ in the volcanic gas is highly soluble in water and can be accumulated, concentrations of chloride in the hot spring water and lake water at the summit are quite low and the fumarolic gases at the summit also contain little $\mathrm{HCl}$. These facts indicate that the geothermal fluids at the summit area cannot be the source of water-soluble chloride in the ejecta. High-temperature gases rich in $\mathrm{HCl}$ were estimated as the source of the Obuki hot spring (Iwasaki et al., 1963). Therefore, high temperature volcanic gases are the most likely source of water-soluble chloride in the ejecta. The high-temperature volcanic gases rose along the old conduits from the depth and caused a steam explosion from the vent close to the 1949 and 1951 craters at Karanuma. It is not clear what triggered the ascent of the volcanic gas from the deep zone.

\section{Conclusions}

Major components, exclusive of the $\mathrm{H}_{2} \mathrm{O}$ of the fumarolic gases at the summit area of Akita-Yakeyama volcano, were $\mathrm{H}_{2} \mathrm{~S}$ and $\mathrm{CO}_{2}$, and the hot spring water and crater lake water were sulfate acidic. Obvious changes of the outlet temperature and chemical composition of the fumarolic gases were not observed before or after the eruption of August 16, 1997. The $\delta \mathrm{D}$ and $\delta^{18} \mathrm{O}$ values for the gas condensates and hot spring water at the Yunuma crater indicate that the fumarolic gases separated from the hot spring water at $150^{\circ} \mathrm{C}$ at a shallow place beneath the Yunuma crater.

Smectite and kaolinite were the major constituents in the clay fraction of the volcanic ejecta and the majority of the ejecta were derived from near the Earth's surface. Although pyrophyllite, which is abundant in the deep zone about $1 \mathrm{~km}$ beneath the summit, was also identified in the clay fraction, that could have been discharged from the deep zone by past eruptions. The deposited pyrophyllite might have been blown away again by the 1997 eruption.

The water leachate of the 1997 volcanic ashes were rich in $\mathrm{Cl}^{-}$and $\mathrm{SO}_{4}^{2-}$ and the $\mathrm{Cl} / \mathrm{S}$ molar values were relatively high. The high $\mathrm{Cl} / \mathrm{S}$ ratio is characteristic of an eruption caused by high-temperature volcanic gases. In contrast, the fumarolic gases at the summit, the acid hot spring water and the crater lake water near the summit area were quite poor in chloride. These facts indicate that the eruption was caused not by geothermal fluids at the summit area but by high-temperature volcanic gases at some depth that have been suggested as the source of the $\mathrm{Cl}-\mathrm{SO}_{4}$ type acid thermal water in this area.

Acknowledgments. We are grateful to Dr. Tsukasa Ohba of Tohoku University and Mr. Kiyohisa Kuroda of HachimantaiOnumasou for providing the volcanic ash samples, and to Dr. Hiroshi Shinohara for helpful suggestions for improving the manuscript. We are also indebted to Dr. Joyo Ossaka for providing us 
with the excellent pictures and Dr. Minoru Yoshida for offering some constructive ideas.

\section{References}

Banba, M. and Y. Kubota, Geothermal Conceptual Model from the viewpoint of the Thermal History in the North Hachimantai-Yakyama Area, Jinetsu, 34, 1-13, 1997 (in Japanese with English abstract).

Epstein, S. and T. K. Mayeda, Variation of ${ }^{18} \mathrm{O}$ content of waters from natural sources, Geochim. Cosmochim. Acta, 4, 213-224, 1953.

Giggenbach, W. F., Isotopic shifts in waters from geothermal and volcanic systems along convergent plate boundaries and thier origin, E. P. S. L., 113, 495-510, 1992.

Hayashi, S., H. Ito, and T. Chiba, 16th August 1997 phreatic explosion of Akita-Yakeyama volcano, northeast Japan, J. Geol. Soc. Japan, 103, XXVII-XXVIII, 1997 (in Japanese).

Henmi, K. and T. Matsuda, Contributions to Clay Mineralogy, Dedicated to Prof. Toshio Sudo, Tokyo Univ. of Education, edited by K. Henmi, pp. 151-156, 1975 (in Japanese with English abstract).

Hirabayashi, J., Change of chemical composition of volcanic gas and volcanic activity, Dr. Thesis, Tokyo Inst. Tech., 190 pp., 1984 (in Japanese)

Hirabayashi, J., J. Ossaka, and T. Ozawa, Relationship between volcanic activity and chemical composition of volcanic gases-A case study on the Sakurajima Volcano, Geochem. J., 16, 11-21, 1982.

Hirabayashi, J., T. Ohba, and K. Nogami, Phreatic eruption of Kuju volcano on October 1995 and geochemical investigation, Reports of October 1995 Phreatic Eruption of Kuji Volcano, 63-74, 1996a (in Japanese).

Hirabayashi, J., T. Ohba, and K. Nogami, Chemical Composition of Volcanic Gases Associated with the 1991-1992 Activity of Shinmoe-dake, Kirishima, Japan, Bull. Volcanol. Soc. Japan, 41, 263-267, 1996b (in Japanese).

Hirabayashi, J., T. Ohba, and K. Nogami, Chemical monitoring for the volcanic activity, Abstracts 1999 Japan Earth and planetary Science Joint Meeting, 1999.

Iwasaki, I., T. Katsura, T. Tarutani, T. Ozawa, M. Yoshida, B. Iwasaki, M. Hirayama, and M. Kamada, Geochemical studies on Tamagawa Hot Springs, in Geochemistry of the Tamagawa Hot Springs (Dedicated to Prof. Eiichi Minami on his sixtieth birthday), 7-72 pp, 1963.

Iwasaki, I., T. Ozawa, M. Yoshida, T. Katsura, B. Iwasaki, and M. Kamada, Differentiation of magmatic emanation, Bull. Tokyo Inst. Tech., 74, 1-57, 1966.

JMA, National catalogue of the active volcanoes in Japan (2nd edition), 93-96, 1996.

Kurosaki, M., J. Ossaka, and T. Matsuda, Clay Minerals in the Volcanic Ejectas from Kusatsu-Shirane Volcano and the Style of Eruption, J. Mineralog. Soc. Japan, 19, 87-91, 1990 (in Japanese with English abstract).

Matsubaya, O., Nessui no Chikyukagaku, 1991 (in Japanese).

Matsubaya, O., H. Etchu, and S. Komuro, Isotopic study of hot springs in Akita prefecture, Rept. Res. Isnt. Underground Resor., Min. Coll., Akita Univ., 48, 11-24, 1983 (in Japanese).
Matsuo, S., M. Kusakabe, H. Chiba, H. Ushiki, J. Ossaka, J. Hirabayashi, T. Abiko, K. Notsu, T. Ozawa, S. Aramaki, K. Sato, T. Hayashi, J. Sato, and N. Fujii, Geochemical Study on Ground Water, Thermal Water and Ash Fall Collected Immediately after the 1977 Eruption of the Usu Volcano, Japan, Bull. Volcanol. Soc. Japan, 22, 201-220, 1977 (in Japanese with English abstract).

Noguchi, K. and H. Kamiya, Prediction of volcanic eruption by measuring the chemical composition and amounts of gases, Bull. Volcanol., 26, 367378, 1963.

Ohba, T. and J. Hirabayashi, Handling of Pt catalyst in $\mathrm{H}_{2}-\mathrm{H}_{2} \mathrm{O}$ equilibration method for D/H measurement of water, Geochem. J., 30, 373-377, 1996.

Ossaka, J., Activity of Volcanoes and Clay Minerals, J. Clay Science Soc. Japan, 22, 127-137, 1982 (in Japanese with English abstract).

Ossaka, J. and T. Ozawa, The 1962-ejecta from Mt.Yake, Nagano-Gifu Prefectures, and its mechanism of eruption, Bull. Volcanol. Soc. Japan, 11, 17-29, 1966 (in Japanese with English abstract).

Ossaka, J. and T. Ozawa, Study on chemical compositions of volcanic gases and volcanic activity at Sakurajima Volcano, Rep. Joint Ob. Sakurajima Volcano, 62-66, 1975 (in Japanese).

Ossaka, J., J. Hirabayashi, T. Ozawa, and K. Kimijima, Monitoring of volcanic gases from Sakurajima and estimation of state of volcanic activity, Rep. 2nd Joint ob. Sakurajima Volcano, 68-80, 1977 (in Japanese).

Ossaka, J., T. Ozawa, H. Sakai, and J. Hirabayashi, Geochemical Study on the Volcanic Activity of Kiso-Ontake Volcano, after the 1979 Eruption, Bull. Volcanol. Soc. Japan, 28, 59-74, 1983 (in Japanese with English abstract).

Ossaka, J., K. Nogami, and J. Hirabayashi, Water-soluble Components on Volcanic ashes from Tokachi-dake Volcano, Hokkaido, Japan during the 1988-1989 Eruption, Bull. Volcanol. Soc. Japan, 43, 25-31, 1998 (in Japanese with English abstract).

Ozawa, T., Chemical analysis of volcanic gases: I, Chemical analysis of volcanic gases containing water vapor, hydrogen chloride, sulfur dioxide, hydrogen sulfide, carbon dioxide, etc., Geochem. Int., 5, 939-947, 1968.

Rose, W. I., Jr., Scavenging of volcanic aerosol by ash: Atmospheric and volcanologic implications, Geology, 5, 621-624, 1977.

Taylor, P. S. and R. E. Stoiber, Soluble materials on ash from active Central American volcanoes, Geol. Soc. Amer. Bull., 84, 1031-1042, 1973.

Tsuya, H., Yakeyama volcano in Akita Pref. and Tamagawa hot spring, Tamagawa Onsen Kenkyukai, 130-135, 1954 (in Japanese).

Ui, T., M. Yoshimoto, R. Furukawa, Y. Ishizuka, M. Yoshida, N. Miyaji, Y. Katsui, N. Kito, Y. Ganzawa, and K. Nogami, March 1996 Eruption of Hokkaido-Komagatake, Northern Japan, Bull. Volcanol. Soc. Japan, 42, 141-151, 1997 (in Japanese with English abstract).

Varekamp, J. C., J. F. Luhr, and K. L. Prestegaard, The 1982 eruptions of El Chichón volcano (Chiapas, Mexico): Character of the eruptions, ash-fall deposits and gasphase, J. V. G. R., 23, 39-68, 1984.

K. Nogami (e-mail: knogami@ksvo.titech.ac.jp), J. Hirabayashi, T. Ohba, and Y. Yoshiike 